\author{
Agnieszka Dembicka-Niemiec \\ https://orcid.org/0000-0003-3992-6989 \\ Uniwersytet Opolski \\ Wydział Ekonomiczny \\ Instytut Geografii Społeczno-Ekonomicznej i Gospodarki Przestrzennej \\ adembicka@uni.opole.pl
}

\title{
ROZWÓJ MIAST METROPOLITALNYCH POLSKI W KONTEKŚCIE ROZWOJU ZRÓWNOWAŻONEGO
}

\begin{abstract}
Abstrakt: Celem artykułu jest określenie poziomu rozwoju zrównoważonego miast metropolitalnych w Polsce w ramach trzech podstawowych wymiarów tego zjawiska. W analizie uwzględniono wymiar społeczny (w tym instytucjonalny), gospodarczy i środowiskowo-przestrzenny. Zastosowano metodę taksonomiczną pozwalającą na porządkowanie badanych jednostek terytorialnych w sposób zhierarchizowany. Określono poziomy ich rozwoju w poszczególnych wymiarach z uwzględnieniem struktury cech, które je opisują. Zidentyfikowanie struktury cech pozwala na określenie, w jakiej odległości od idealnej struktury tych cech są badane miasta. Badania przeprowadzono w ujęciu dynamicznym, analizując cztery wybrane okresy czasowe (2002, 2007, 2015 i 2019 r.). Badania pokazały, że każde z badanych miast cechuje duże zróżnicowanie struktury opisujących je cech oraz duże podobieństwo w zakresie osiąganych poziomów rozwoju.
\end{abstract}

Słowa kluczowe: zrównoważony rozwój, metropolie, rozwój miast.

\section{THE DEVELOPMENT OF POLISH METROPOLITAN CITIES IN THE CONTEXT OF SUSTAINABLE DEVELOPMENT}

Abstract: The aim of the work is to determine the level of sustainable development of metropolitan cities in Poland within its basic dimensions. Three main dimensions have been considered: social, economic and environmental, and spatial. A taxonomic method was used that allows the territorial units analyzed to be organized in a hierarchical manner. The levels of their development in particular dimensions were determined, taking into account the level of development as well as the structure of the features that describe them while identifying these features allows their distance from the ideal to be determined. The research was carried out across time analyzing four selected years: 2002, 2007, 2015, 2019. The local governments studied may be at different levels of development but may in fact have similar features or vice versa. Each of the cities examined is characterized by a large differentiation of the features describing them and a great similarity in terms of the levels of development achieved.

Keywords: sustainable development, metropolises, urban development.

\section{WPROWADZENIE}

Koncepcja rozwoju zrównoważonego od końca lat 80. XX w. wciąż zyskuje na znaczeniu, a jej realizacja ma na celu m.in. poprawę jakości życia w miastach oraz ochronę środowiska. Za początki jej popularyzacji uznaje się ogłoszony w 1987 r. Raport Światowej Komisji do Spraw Środowiska i Rozwoju, znany też jako Raport Brundtland. Treść tego dokumentu wskazywała m.in. na konieczność zachowania ogólnoświatowego ładu społeczno-gospodarczego i środowiskowego, bo tylko w taki sposób można zapewnić rozwój, który „zaspokoiłby potrzeby obecne, nie pozbawiając przyszłych pokoleń możliwości zaspokojenia ich potrzeb" (Brundtland, 1987, s. 42). Stosunek do zagadnienia rozwoju zrównoważonego ewoluował, niemniej jednak koncepcja ta oznacza potrzebę dążenia do zrównoważonego i trwałego rozwoju poprzez oszczędne i racjonalne gospodarowanie zasobami. Określenie „zasoby” w odniesieniu do miasta oznacza przestrzeń, surowce, energię i kapitał, ale również tzw. zasoby ludzkie, kapitał społeczny oraz czas (np. mieszkańców) (Stangel, 2013). W literaturze przedmiotu wskazuje się często na trzy główne wymiary (kapitały) rozwoju zrównoważonego: ekonomiczny, społeczny i naturalny, zwany również środowiskowym, lub środowiskowo-przestrzennym (por. Ciegis, Ramanauskiene, Martinkus, 2009; Elkington, 1994; Harris, 2003; Moffatt, 2000). W 2015 r. określono Cele Zrównoważonego Rozwoju, które zastąpiły wcześniej sformułowane 
Milenijne Cele Zrównoważonego Rozwoju. W znacznej mierze obejmują one również sektor prywatny oraz dużo szerszy horyzont czasowy (do 2030 r.) (Global Compact Network Poland, 2021). Cele te są ściśle powiązane z wymiarami zrównoważonego rozwoju, a czynności prowadzące do ich realizacji wpisują się w działania na rzecz poszczególnych jego wymiarów. W tematyce rozwoju zrównoważonego warto zwrócić uwagę na model ekonomiczny, jakim jest doughnut economy (model ekonomiczny pączka), który uwzględnia wyniki gospodarki pod względem stopnia zaspokojenia potrzeb ludzi bez przekraczania pułapu ekologicznego Ziemi. Model ten oparty jest na fundamentach społecznych, których podstawą jest wymiar społeczny rozwoju zrównoważonego, jak i na pułapach ekologicznych (Raworth, 2017). Ekonomia pączka opiera się na innym od dotychczasowego wyobrażeniu o dobrobycie, który osiągany jest wyłącznie dzięki nieustannemu wzrostowi gospodarczemu i działaniom podporządkowanym prawom popytu i podaży. Autorka tej koncepcji, Kate Raworth, twierdzi, że globalna gospodarka może dobrze prosperować również wtedy, gdy oprze się ją na fundamentach społecznych, mieszczących się w ramach pułapów ekologicznych. Należy zatem zapewnić mieszkańcom dobre pod względem ekonomicznym warunki do życia z całkowitym poszanowaniem zasad ekologii. Biorąc pod uwagę rozwój terenów zurbanizowanych, a zwłaszcza metropolii, dominującym obszarem rozwoju jest gospodarka, będąca swoistym motorem napędowym i centrum przyciągania inwestycji. Uwidacznia się zatem wyższość wymiaru gospodarczego nad społecznym czy środowiskowym, zaś w modelu ekonomicznym pączka jest odwrotnie

W literaturze przedmiotu wskazuje się na pewne ramy wytyczające realizację działań w zakresie wymiarów rozwoju zrównoważonego w praktyce. Ramy te wskazują na istnienie wzajemnej zależności wszystkich obszarów działalności ekonomicznej, środowiskowej i społecznej - uznając te obszary za elementy składowe planowania przyszłych działań oraz dążeń do trwałości rozwoju ludzkiego. W koncepcji tej zakłada się holistyczne podejście do podejmowania działań i rozwiązywania problemów z zastosowaniem myślenia systemowego i uznawaniem sprawiedliwości międzypokoleniowej (Ekins, 1992). Takie ramy umożliwiają działanie na rzecz rozwoju zrównoważonego w różnych skalach i na różnych obszarach. Na przykład samorządy i rządy mogą wykorzystywać ramy rozwoju zrównoważonego do prowadzenia kompleksowej, zintegrowanej polityki i strategii planowania, a lokalne społeczności mogą korzystać z nich do zrozumienia sytuacji i planowania przyszłości. Jest to podstawa do systemowego ujęcia funkcjonowania miast. Przedsiębiorstwa realizujące założenia społecznej odpowiedzialności biznesu ograniczają swój negatywny wpływ na środowisko i społeczeństwo. Rozwój gospodarczy dominuje w miastach metropolitalnych, ale mimo wszystko należy uwzględniać zagadnienia z obszaru działalności społecznej, dotyczące potrzeb społeczności lokalnych, jak i środowiskowej.

W ostatnich latach rośnie zainteresowanie ekologią oraz zasadami rozwoju zrównoważonego, które wynikają z potrzeby reagowania na pojawiające się problemy w funkcjonowaniu miast. Te jednostki terytorialne wymagaja, aby podejmowane wobec nich działania miały charakter interdyscyplinarny, bowiem to właśnie miasta w znacznym stopniu wpływają na przekształcanie środowiska przyrodniczego i są istotnym źródłem emisji zanieczyszczeń. Ponadto, w miastach zużywa się najwięcej energii, co sprawia, że należy w szczególny sposób zająć się wdrażaniem technologii opartych na odnawialnych źródłach energii.

Zasady rozwoju zrównoważonego próbuje się wprowadzać na różnych szczeblach organizacji terytorialnej. Przy czym największe efekty osiąga się na poziomie lokalnym, bowiem to właśnie w obrębie miast i gmin najtrafniej można zidentyfikować występujące problemy i na nie zareagować. Uważa się, że to szczebel lokalny jest tym najbardziej odpowiednim do realizacji założeń rozwoju zrównoważonego. Jednak nie jest to działanie jednolite, bowiem jednostki terytorialne różnią się od siebie, co sprawia, że nie da się zastosować jednego schematu do rozwiązywania podobnych problemów. Dlatego też przyjmuje się odmienną politykę rozwoju zrównoważonego, w zależności od warunków jakie mają miasta bądź gminy. Zatem zarówno strategie, jak i programy rozwoju zrównoważonego muszą uwzględniać nie tylko cele opisane w dokumencie Our common future (Brundtland, 1987), ale także specyficzny charakter i odmienność danej jednostki. Oczywiście istnieją też wspólne dla większości miast problemy - skala ich występowania jest większa bądź mniejsza i podejmuje się wobec nich odpowiednie działania, takie jak: walka ze smogiem, usprawnienie funkcjonowania transportu, walka z wykluczeniem społecznym, rozwój przedsiębiorczości, wsparcie innowacyjności i wiele innych.

Rozwój zrównoważony rozpatrywany jest najczęściej w trzech wymiarach: ekonomicznym, społecznym i środowiskowym bądź też środowiskowo-przestrzennym. Takie podejście odzwierciedla system gospodarczo-społeczno-ekologiczny funkcjonowania człowieka i jednostek terytorialnych różnych szczebli, w tym także miast. Ścisłe powiązanie elementów systemu sprawia, że są one od siebie zależne. Zachwianie równowagi w ramach działania systemu przejawia się poprawą stanu jednego z jego elementów z jednoczesnym pogorszeniem innego (Rzeńca, 2016).

Dążenie do trwałości funkcjonowania miast jest istotne i powinno być uwzględniane w polityce rozwoju każdego miasta. Trzeba również pamiętać, że miasta jako jednostki terytorialne są w znacznej mierze uzależnione od otoczenia (choćby pod względem zaopatrywania się w żywność) i są ściśle z nim powiązane. 
Biorąc pod uwagę dynamiczny proces metropolizacji, pojawia się wyzwanie, aby był on zgodny z zasadami rozwoju zrównoważonego. Obecnie rozwój wielkich miast powoduje nadmierny wzrost popytu na zasoby naturalne, zmniejszenie różnorodności biologicznej, zwiększenie presji na ekosystem oraz wzrost zużycia energii (Szwed, Maciejewska, 2010)

Przeprowadzone badanie miało na celu zidentyfikowanie kierunków rozwoju miast metropolitalnych w Polsce oraz określenie, czy zachodzące w nich zmiany są pożądane czy niepożądane w myśl koncepcji rozwoju zrównoważonego.

\section{IDENTYFIKACJA}

\section{MIAST METROPOLITALNYCH W POLSCE}

Analiza literatury przedmiotu dotyczącej zagadnienia metropolii wskazuje na różną identyfikację ośrodków (miast) pełniących funkcje metropolitalne, co jest wynikiem stosowania niejednakowych kryteriów stawianych metropoliom oraz używania do ich określania rozmaitych terminów.

Jednostki terytorialne ze względu na typ obszaru w Polsce identyfikuje się na podstawie kryteriów zawartych w Koncepcji Przestrzennego Zagospodarowania Kraju 2030 (2011). Zgodnie z dokumentem do 2030 r. ośrodki metropolitalne wyróżnia się ze względu na:

- wielkość (co najmniej 300 tys. mieszkańców),

- pełnienie istotnych funkcji o zasięgu co najmniej ponadregionalnym,

- pełnienie roli ośrodka ponadregionalnego,

- istnienie wartościowych zespołów urbanistycznych. Na podstawie wyszczególnionych we wspomnianym dokumencie kryteriów za ośrodki metropolitalne w Polsce uznaje się: Warszawę (metropolia stołeczna), Kraków, Gdańsk (Gdańsk - Gdynia), Wrocław, Poznań, Katowice (Konurbacja Śląska), Łódź, Szczecin, Bydgoszcz (Bydgoszcz - Toruń), Lublin. Odmienną klasyfikację metropolii przedstawiają naukowcy i badacze obszarów miejskich. Przykładowo Ilnicki (2003) dokonał analizy funkcji metropolitalnych w Polsce i wyróżnił jedną metropolię kontynentalną oraz sześć ośrodków, które można zaliczyć do grona potencjalnych metropolii kontynentalnych (Poznań, Wrocław, Gdańsk, Kraków, Łódź i Katowice). Podobną klasyfikację ośrodków metropolitalnych przedstawili M. Smętkowski, B. Jałowiecki i G. Gorzelak. Na podstawie przeprowadzonych badań wyróżniają oni duże miasta, grupując je w trzy zbiory (Smętkowski, Jałowiecki, Gorzelak, 2009):

- ośrodki metropolitalne (Warszawa, Katowice, Kraków, Poznań, Trójmiasto, Wrocław i Łódź);

- ośrodki regionalne - klasa A (Lublin, Szczecin i Toruń);

- ośrodki regionalne - klasa B (Białystok, Bielsko-Biała, Bydgoszcz, Częstochowa, Kielce, Olsztyn i Rzeszów).
Z kolei Markowski oraz Marszał metropolie klasyfikują jako ponadregionalne (Warszawa), metropolie krajowe (Kraków, Trójmiasto, Wrocław, Poznań, Łódź) oraz miasta, które mają potencjał do bycia metropolią, takie jak: Szczecin, Lublin, Białystok, Rzeszów i aglomeracja bydgosko-toruńska (Markowski, Marszał, 2006).

Analiza różnych klasyfikacji metropolii w Polsce skłoniła do przeprowadzenia badania wśród siedmiu miast: Warszawy, Wrocławia, Katowic, Krakowa, Poznania, Łodzi i Gdańska, zaliczanych według wielu badaczy do miast metropolitalnych.

\section{CEL I ZAŁOŻENIA METODOLOGICZNE BADAŃ}

Celem badań było określenie poziomu rozwoju zrównoważonego miast metropolitalnych w Polsce w ramach podstawowych wymiarów tego zjawiska. W analizie uwzględniono trzy główne aspekty rozwoju zrównoważonego: społeczny (w tym zawarty został wymiar instytucjonalny), gospodarczy i środowiskowo-przestrzenny. Określono poziomy ich rozwoju z uwzględnieniem struktury cech, które je opisują. Zidentyfikowanie struktury cech pozwoliło na oszacowanie, w jakiej odległości od idealnej struktury tych cech są badane miasta. W przeprowadzonym badaniu użyto metody taksonomicznej zwanej metodą Michalskiego (2001). Pozwoliła ona na uporządkowanie badanych jednostek terytorialnych w sposób zhierarchizowany.

Badania przeprowadzono w ujęciu dynamicznym, analizując cztery wybrane momenty czasowe (2002, 2007, 2015 i 2019 r.). Na dobór momentów do badań wpływ miały dostępność i rzetelność danych statystycznych oraz wydarzenia, które mogły oddziaływać na rozwój metropolii, takie jak np. akces Polski do Unii Europejskiej (UE) w 2004 r. Za istotne uznano przedstawienie obrazu metropolii na krótko przed przystąpieniem Polski do UE, jak i krótko po, aby zaobserwować zmiany wynikające z dostępności do funduszy europejskich oraz realizacji celów wspólnej polityki UE, w tym polityki rozwoju zrównoważonego. Ponadto w 2003 r. po raz pierwszy w Polsce pojawiło się pojęcie metropolii, nawiązujące do standardów międzynarodowych (Zuzańska-Żyśko, 2016), co również mogło mieć wpływ na kierunek prowadzonej przez miasta polityki rozwoju. Efekty 10 lat realizacji polityki wspólnotowej widoczne są w 2015 r., natomiast najbardziej aktualne i kompletne dane statystyczne pochodzą z 2019 r. Należy zaznaczyć, że w literaturze przedmiotu wskazuje się na różne momenty rozpoczęcia procesu metropolizacji w Polsce. W przypadku stolicy kraju przyjmuje się końcówkę lat 90., a odnośnie pozostałych największych polskich miast początek XXI w. (Zuzańska-Żyśko, 2016). 
Dlatego też wybranie kilku momentów czasowych po 2000 r. wydaje się uzasadnione.

Obiektami badania są miasta metropolitalne w Polsce. Badania przeprowadzono z uwzględnieniem trzech wymiarów rozwoju zrównoważonego: społecznego, gospodarczego i środowiskowo-przestrzennego. Rozpatrywanie tych trzech wymiarów było podyktowane analizą literatury, z której wynika, że właśnie te wymiary są najistotniejsze oraz zostały w ten sposób pogrupowane na liście wskaźników rozwoju zrównoważonego Systemu Analiz Samorządowych (2020). Wymiar instytucjonalno-polityczny w tym przypadku jest zawarty w wymiarze społecznym.

Funkcjonowanie miast metropolitalnych zależne jest od różnych uwarunkowań i czynników rozwoju oraz polityki prowadzonej przez władze, a wszystko to wpływa na ich specyfikę, kształt i kierunki rozwoju. Dlatego też, aby określić, które z miast metropolitalnych polski cechują się silnym rozwojem w wymiarze gospodarczym, społecznym czy środowiskowo-przestrzennym, a które słabym, miasta te należałoby porównać. Jest to jednak niemożliwe do wykonania przy uwzględnianiu jedynie zestawu wskaźników opisujących miasta oraz z powodu odmiennych uwarunkowań rozwoju tych jednostek. W artykule zastosowano zatem metodę pozwalającą na uporządkowanie miast ze względu na osiągane poziomy rozwoju, przyjmując, że obiektem wzorcowym jest jednostka, która charakteryzuje się najlepszymi cechami ze wszystkich badanych.

W modelu wyznaczono m.in. wartości taksonomicznych miar podobieństwa struktur oraz podobieństwa poziomów cech, określających dany wymiar rozwoju zrównoważonego miast metropolitalnych w porównaniu do wymiarów obiektu wzorcowego w latach 2002, 2007, 2015, 2019. Za cechę uważa się wskaźniki rozwoju zrównoważonego.

Postępowanie w zastosowanej metodzie składa się z następujących etapów (Dembicka-Niemiec, 2017):

1. Cechy podzielono na stymulanty ${ }^{1}$ i destymulanty ${ }^{2}$, a cechy o charakterze nominant zostały odrzucone.

2. Dokonano standaryzacji cech i kolejno stworzono macierz obserwacji $\mathrm{X}^{\mathrm{j}} \mathrm{w}$ roku $j$, według wzoru:

$$
z_{i w}^{j}=\frac{x_{i w}^{j}-\bar{x}_{w}}{s_{w}}
$$

gdzie:

w - liczba cech, wskaźników,

$\hat{Y}-$ wartość cechy $w(w=1, \ldots, W) \mathrm{w} \operatorname{roku} j(j=1, \ldots, l)$ i mieście $i(i=1, \ldots, m)$,

- odchylenie standardowe cechy $w$,

- - średnia wartość cechy w.

3. Odchylenie standardowe i średnią wyliczono dla całego okresu badania i tworzą macierz $\mathrm{Z}^{j}$ standaryzowanych wartości cech, po to aby wyznaczyć

macierz korelacji cech $\quad R=\frac{1}{n} Z^{T} Z$
4. Przeprowadzono eliminację zmiennych zgodnie z procedurą określania zmiennych diagnostycznych. Rozważania te są istotne, bowiem miasta na danym poziomie rozwoju zrównoważonego niekoniecznie mają taką samą strukturę analizowanego zagadnienia. Identyfikacja stopnia podobieństwa struktury zjawiska dla danego miasta ze strukturą idealną dostarcza informacji o stopniu zrównoważonego rozwoju tego miasta.

Aby określić stopień podobieństwa badanych jednostek ze względu na strukturę cech diagnostycznych wykorzystano miarę $\mu(i ; j)$, przedstawiającą podobieństwo struktur cech i-tego miasta metropolitalnego z obiektem wzorcowym. Konstrukcja obiektu wzorcowego polegała na wyznaczeniu najwyższej wartości dla każdej z cech w badanym zbiorze miast. Wzorzec ma charakter abstrakcyjny, bowiem został określony na podstawie wartości zawartych w macierzy informacji w ten sposób, że dla stymulant przyjął odpowiednio wartości maksymalne, a dla destymulant wartości minimalne. Żaden z przyjętych do badania wskaźników nie miał charakteru nominanty. Jednocześnie należy podkreślić, że najwyższa wartość wskaźnika w badanej grupie miast nie oznacza, że wartość ta jest optymalna, bowiem obiekt wzorcowy dotyczy jedynie badanego zbioru miast metropolitalnych.

W procesie konstrukcji miary pozwalającej na ocenę podobieństwa struktur cech diagnostycznych w mieście i-tym i obiekcie wzorcowym, wykorzystane zostały wektory $z_{i}$ oraz $z_{p}$. Miara podobieństwa struktur dana jest wzorem:

$$
\mu(i ; p)=\frac{z_{i}^{*} z_{p}}{\left|z_{i}\right|\left|z_{p}\right|}
$$

gdzie:

- i-ty wiersz macierzy Z (i-ty obiekt),

- p-ty wiersz macierzy Z (obiekt wzorcowy),

- iloczyn skalarny wektorów $z_{i^{\prime}} z_{p^{\prime}}$

- długość wektora $z_{i^{\prime}}$

- długość wektora $z_{p}$.

Miarę $\mu(i ; p)$ poddano normalizacji, aby wyeliminować przyjmowanie wartości z przedziału <-1,1>. Unormowana miara $\mu^{*}(i ; p)$ dana jest wzorem:

$$
\mu^{*}(i ; p)=\frac{1+\mu(i ; p)}{2}
$$

Unormowana miara $\mu^{*}(i ; p)$ przyjmuje wartości z przedziału <0,1> i oznacza, że im większa wartość wskaźnika podobieństwa, tym obiekty są bardziej do siebie podobne.

Im wartość wskaźnika $\mu^{*}(i ; p)$ była wyższa, tym miasto było bardziej podobne do obiektu wzorcowego, czyli charakteryzowało się zbliżoną do pożądanej strukturą cech diagnostycznych. Zarówno w zakresie presji, jak i reakcji został zidentyfikowany osobny 
wzorzec, określający strukturę oraz poziom rozwoju miast.

Jako drugą wprowadzono miarę odległości, która przedstawia poziom wartości cech diagnostycznych, opisujaccych badane miasta metropolitalne. Wariant miary odległości pozwala na pomiar dystansu między obiektami, uwzględniając ich podobieństwo ze względu na zróżnicowanie poziomu wartości cech diagnostycznych.

Miara $d^{*}(i ; p)$ dana jest wzorem:

$$
d^{*}(i ; p)=1 \quad \frac{1}{2 \sqrt{k n}} d(i ; p)
$$

$k$ - liczba cech,

$n$ - liczba miast

gdzie:

$$
d(i ; p)=\sqrt{\sum_{j=1}^{k}\left(z_{i j}-z_{p j}\right)^{2}}
$$

Miara $d^{*}(i ; p)$ przyjmuje wartości z przedziału $<0 ; 1>$ i oznacza, że im wartość wskaźnika jest bliższa jedności, tym obiekty mniej różnią się poziomem cech diagnostycznych w stosunku do obiektu wzorcowego. Istotne wydaje się wyjaśnienie różnicy pomiędzy poziomem wartości cech diagnostycznych a ich strukturą. W badaniu mogą wystąpić bowiem jednostki o tym samym poziomie rozwoju, ale innej strukturze cech diagnostycznych (miasto A może mieć taką samą strukturę cech jak miasto B, np. A: 5555, B: 2222, ale poziom cech jest odmienny).

Analiza miar taksonomicznych pozwoliła na odpowiedź na następujące pytania:

1. Jaki jest poziom cech charakteryzujących badane miasta metropolitalne w zakresie rozwoju zrównoważonego w wymiarze społecznym, gospodarczym i środowiskowo-przestrzennym.

2. Jaka jest struktura cech charakteryzujących poszczególne miasta metropolitalne w zakresie rozwoju zrównoważonego w wymiarze społecznym, gospodarczym i środowiskowo-przestrzennym.

Początkowo zestaw potencjalnych wskaźników obejmował 221 cech i był oparty na wskaźnikach rozwoju zrównoważonego Systemu Analiz Samorządowych w ramach trzech wymiarów: społecznego, gospodarczego i środowiskowo-przestrzennego (System Analiz Samorządowych, 2020). Podczas procesu doboru zmiennych do badania wyeliminowano zmienne niekompletne w wybranych momentach czasowych, wysoko ze sobą skorelowane $(>0,8)$ oraz te, których współczynnik zmienności był niski $(<10 \%)$. Ostateczny zestaw zmiennych zawierał: 9 cech opisujących wymiar społeczny, 10 cech opisujących wymiar gospodarczy, 9 cech charakteryzujących wymiar środowiskowo-przestrzenny (zob. załącznik 1).

\section{WYMIARY ROZWOJU ZRÓWNOWAŻONEGO MIAST METROPOLITALNYCH}

Aby zbadać, czy miasta rozwijają się w sposób zrównoważony, dla każdego z nich wykonano analizę podobieństwa poziomów cech $\mathrm{w}$ ramach trzech wymiarów. Idea takiej prezentacji sprowadza się do tego, że na osiach wykresu radarowego odkłada się wartości miar podobieństwa dla odpowiednich wymiarów rozwoju zrównoważonego i w efekcie każdy wykres jest graficzną prezentacją analizowanego miasta, uwzględniającą rozważane wymiary. Im bardziej wartości na wykresie zbliżają się do 1, tym miasto lepiej rozwija się w danym wymiarze rozwoju zrównoważonego w relacji do pozostałych miast metropolitalnych. Rozwój miast w każdym z wymiarów został przedstawiony na wykresach radarowych (rys. 1).

Analizując dane zobrazowane na wykresie (rys. 1), można zauważyć, że jeśli kształty przybierają formę najbardziej zbliżoną do trójkąta równoramiennego, to znaczy, że miasto rozwija się bardziej równomiernie w ramach trzech wymiarów zrównoważonego rozwoju na tle pozostałych badanych jednostek.

Należy wziąć pod uwagę, że stan miasta zrównoważonego (idealnego) uznaje się za trudny do osiągnięcia i postrzega się go raczej w kategoriach odpowiedniej równowagi pomiędzy poszczególnymi elementami systemu miasta niż kojarzy z podtrzymywalnością rozwoju miasta, o której mowa w raporcie Nasza Wspólna Przyszłość (Grzelońska, Kolanowska, 1991). Niemniej jednak przeprowadzone badania wskazują na pewne tendencje oraz kierunki zmian i dają możliwość porównania miast metropolitalnych Polski. Analiza wyników badań wskazuje, że miastem, którego poziom rozwoju jednego z wymiarów jest zbliżony do poziomu prezentowanego przez pozostałe wymiary, jest Warszawa. W badanej grupie miast metropolitalnych można zauważyć, że część z nich wyróżnia się silnym rozwojem w ramach wymiaru środowiskowo-przestrzennego (Gdańsk, Poznań). Pozostałe miasta charakteryzują się zróżnicowanymi poziomami rozwoju w ramach analizowanych wymiarów (Kraków, Katowice, Łódź, Wrocław, Warszawa). Zmiany w osiąganych przez miasta poziomach rozwoju poszczególnych wymiarów miały różny charakter. Na uwagę zasługują Łódź oraz Katowice, które charakteryzowały się niejednoznacznym kierunkiem zmian w ramach analizowanych wymiarów rozwoju zrównoważonego. W przypadku Łodzi, w pierwszych badanych momentach czasowych miasto było najbardziej zbliżone do obiektu wzorcowego w ramach wymiaru środowiskowego. W wymiarze społecznym natomiast zauważalna była tendencja niejednokierunkowa. W 2007 r. miasto poprawiło wartość miary $d_{i}$ z 0,64 na 0,66, w kolejnym roku wartość ta uległa zmniejszeniu $(0,65)$, a w 2019 r. nastąpił widoczny wzrost $(0,68)$. Jednak 


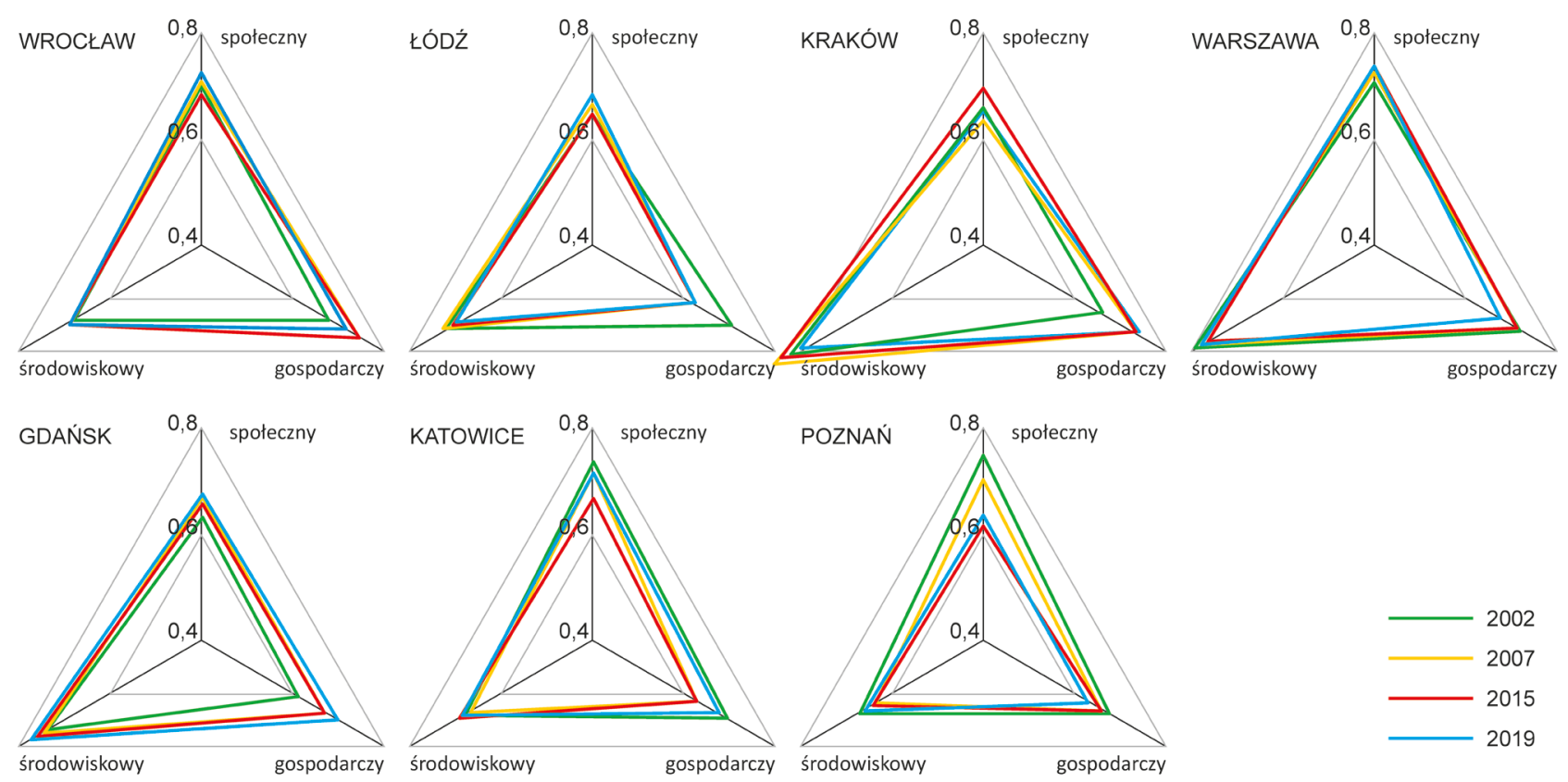

Rysunek 1. Proporcjonalność wymiarów zrównoważonego rozwoju badanych miast Źródło: opracowanie własne

miasto charakteryzowało się największymi wartościami $\mathrm{w}$ wymiarze środowiskowo-przestrzennym $\mathrm{z}$ tendencją do ich zmniejszania. Łódź cechowała tym samym prawidłowość oddalania się od obiektu wzorcowego w przypadku wymiaru gospodarczego.

Kształtowanie się wartości miary podobieństwa poziomów cech do obiektu wzorcowego dla Katowic wskazuje na oddalanie się od wzorca w wymiarze społecznym i gospodarczym. Natomiast $\mathrm{w}$ wymiarze środowiskowo-przestrzennym widoczna jest niewielka poprawa wartości miernika $d_{i}$ (z 0,68 w 2002 r. na 0,69 w 2019 r.).

Istota jest zatem dynamika zmian $\mathrm{w}$ poszczególnych wymiarach, jak i osiagane poziomy rozwoju (poziom wartości cech opisujących dany wymiar). Metropolia, która wyróżniała się najmniejszymi zmianami w analizowanych latach i która równocześnie osiągała najwyższe miary poziomu rozwoju we wszystkich trzech wymiarach w 2019 r., był Wrocław. Z kolei największa dynamika zmian charakterystyczna była dla Krakowa. Współczynnik zmienności dla wszystkich wymiarów rozwoju zrównoważonego $\mathrm{w}$ badanym okresie wynosił 0,46 , podczas gdy dla pozostałych miast zawierał się w przedziale $0,14-0,32$.

\section{PODOBIEŃSTWO POZIOMU CECH ORAZ STRUKTURY CECH OPISUJĄCYCH BADANE JEDNOSTKI}

Aby zobrazować tendencje zmian $\mathrm{w}$ badanych latach oraz ich poziomy rozwoju względem siebie, warto przedstawić zestawienie miast $\mathrm{w}$ rankingu (tab. 1).
Polskie miasta metropolitalne rozwijają się w sposób dynamiczny, co sprawia, że zajmują one różne pozycje w klasyfikacji miast w poszczególnych wymiarach rozwoju zrównoważonego. Biorąc pod uwagę zmiany w zakresie poziomów cech w wymiarze gospodarczym (tab. 1), miastem, które widocznie poprawiło swoją pozycję w rankingu, był Kraków (miejsce szóste w 2002 r.; miejsce drugie w 2007r.; miejsce pierwsze w 2019 r.). Podobnie było w przypadku Gdańska, który w 2002 r. zajmował ostatnią pozycję $\mathrm{w}$ rankingu, jednak w badanych latach poprawiał swoje notowania i ostatecznie uplasował się na trzecim miejscu. Odwrotny trend charakteryzował Łódź, która w 2019 r. była miastem o najniższym poziomie rozwoju gospodarczego, podczas gdy w 2002 r. zajmowała drugie miejsce w rankingu. W przypadku wymiaru społecznego, wśród grupy badanych miast metropolitalnych występowały takie, które ostatecznie pogorszyły swoje pozycje w klasyfikacji (Katowice, Kraków), jak i te, które uplasowały się na wyższych miejscach (Gdańsk, Warszawa, Wrocław, Łódź). Jedynym miastem, które odnotowało stosunkowo niskie wartości w zakresie poziomów cech był Poznań, który w $2002 \mathrm{r}$. zajmował pierwsze miejsce $\mathrm{w}$ rankingu, a w 2019 r. już ostatnie. Zmiany pozycji miast $\mathrm{w}$ klasyfikacji w przypadku wymiaru środowiskowo-przestrzennego były równie zróżnicowane, jak w wymiarze społecznym. Analiza danych wskazuje, że Kraków i Poznań nie zmieniły swojej pozycji, natomiast Gdańsk i Wrocław poprawiły swoje notowania w badanych latach. W przypadku pozostałych miast widoczny jest spadek pozycji w rankingu miast metropolitalnych (Warszawa, Łódź, Katowice). Zaskakuje zwłaszcza pozycja Krakowa, który przez wszystkie badane momenty 
Tabela 1. Ranking miast ze względu na podobieństwo poziomu cech do wzorca w ramach poszczególnych wymiarów rozwoju zrównoważonego

\begin{tabular}{|c|c|c|c|c|c|c|c|}
\hline \multicolumn{8}{|c|}{ Wymiar społeczny } \\
\hline & 2002 & & 2007 & & 2015 & & 2019 \\
\hline Poznań & 0,75 & Warszawa & 0,73 & Warszawa & 0,74 & Warszawa & 0,73 \\
\hline Katowice & 0,74 & Katowice & 0,72 & Kraków & 0,70 & Wrocław & 0,73 \\
\hline Warszawa & 0,71 & Wrocław & 0,71 & Wrocław & 0,68 & Katowice & 0,71 \\
\hline Wrocław & 0,70 & Poznań & 0,70 & Katowice & 0,67 & Łódź & 0,68 \\
\hline Kraków & 0,66 & Gdańsk & 0,67 & Gdańsk & 0,66 & Gdańsk & 0,67 \\
\hline Łódź & 0,64 & Łódź & 0,66 & Łódź & 0,65 & Kraków & 0,65 \\
\hline Gdańsk & 0,63 & Kraków & 0,63 & Poznań & 0,62 & Poznań & 0,63 \\
\hline \multicolumn{8}{|c|}{ Wymiar gospodarczy } \\
\hline & 2002 & & 2007 & & 2015 & & 2019 \\
\hline Warszawa & 0,72 & Wrocław & 0,75 & Wrocław & 0,75 & Kraków & 0,73 \\
\hline Łódź & 0,70 & Kraków & 0,72 & Kraków & 0,72 & Wrocław & 0,72 \\
\hline Katowice & 0,70 & Warszawa & 0,71 & Warszawa & 0,71 & Gdańsk & 0,70 \\
\hline Wrocław & 0,69 & Gdańsk & 0,67 & Gdańsk & 0,67 & Warszawa & 0,68 \\
\hline Poznań & 0,68 & Poznań & 0,66 & Poznań & 0,66 & Katowice & 0,68 \\
\hline Kraków & 0,66 & Katowice & 0,63 & Katowice & 0,63 & Poznań & 0,63 \\
\hline Gdańsk & 0,61 & Łódź & 0,62 & Łódź & 0,62 & Łódź & 0,62 \\
\hline \multicolumn{8}{|c|}{ Wymiar środowiskowo-przestrzenny } \\
\hline & 2002 & & 2007 & & 2015 & & 2019 \\
\hline Kraków & 0,81 & Kraków & 0,85 & Kraków & 0,83 & Kraków & 0,79 \\
\hline Warszawa & 0,79 & Warszawa & 0,78 & Warszawa & 0,76 & Gdańsk & 0,77 \\
\hline Gdańsk & 0,74 & Gdańsk & 0,75 & Gdańsk & 0,76 & Warszawa & 0,77 \\
\hline Łódź & 0,72 & Łódź & 0,72 & Łódź & 0,70 & Wrocław & 0,70 \\
\hline Katowice & 0,68 & Wrocław & 0,69 & Katowice & 0,70 & Łódź & 0,69 \\
\hline Wrocław & 0,67 & Katowice & 0,67 & Wrocław & 0,69 & Katowice & 0,69 \\
\hline Poznań & 0,67 & Poznań & 0,63 & Poznań & 0,64 & Poznań & 0,66 \\
\hline
\end{tabular}

Źródło: opracowanie własne.

czasowe zajmował pierwsze miejsce $\mathrm{w}$ rankingu i kojarzony jest $\mathrm{z}$ wysokim poziomem zanieczyszczenia powietrza. Zanieczyszczenie to rzeczywiście występuje i jakość powietrza w mieście nie należy do najlepszych, ale pozostałe wskaźniki charakteryzujące miasto są jednymi z wyższych, np. powierzchnia parków krajobrazowych w powierzchni gminy ogółem, powierzchnia obszarów prawnie chronionych w ha na 1000 mieszkańców. Dodatkowo Kraków cechuje jeden z niższych odsetków ścieków komunalnych i przemysłowych nieoczyszczanych w ogólnej ilości wytwarzanych ścieków.

Zmiany w zakresie struktury cech były bardziej dynamiczne niż $\mathrm{w}$ przypadku miary poziomów cech. $W$ celu zobrazowania różnic $w$ tym zakresie przedstawiono miasta na wykresach radarowych dla poszczególnych wymiarów rozwoju zrównoważonego (rys. 2).

Polskie miasta metropolitalne charakteryzują się wysokim poziomem rozwoju w wymiarze gospodarczym oraz środowiskowo-przestrzennym, a niższym w wymiarze społecznym. Świadczą o tym osiągane przez miasta wartości miar syntetycznych. Biorąc pod uwagę poziom rozwoju badanych jednostek, stwierdza się, że miasta są do siebie zbliżone $\mathrm{w}$ zakresie osiąganych wartości. Inaczej wyniki otrzymywane są w odniesieniu do struktury cech opisujących te miasta, która jest zróżnicowana w każdym wymiarze rozwoju zrównoważonego i cechuje się większymi zmianami (rys. 2). Wykresy radarowe wskazują na największe różnice w strukturze cech w ramach wymiaru środowiskowo-przestrzennego. Oznacza to, że badane jednostki znacznie różnią się od siebie pod tym względem. Szczególnie niekorzystne wyniki mają Poznań oraz Łodzi, dla których odnotowano wyraźne oddalenie się od obiektu wzorcowego ich struktury cech. W zakresie pozostałych dwóch wymiarów rozwoju zrównoważonego widoczne są mniejsze różnice w prezentowanych przez miasta strukturach cech je opisujących. 


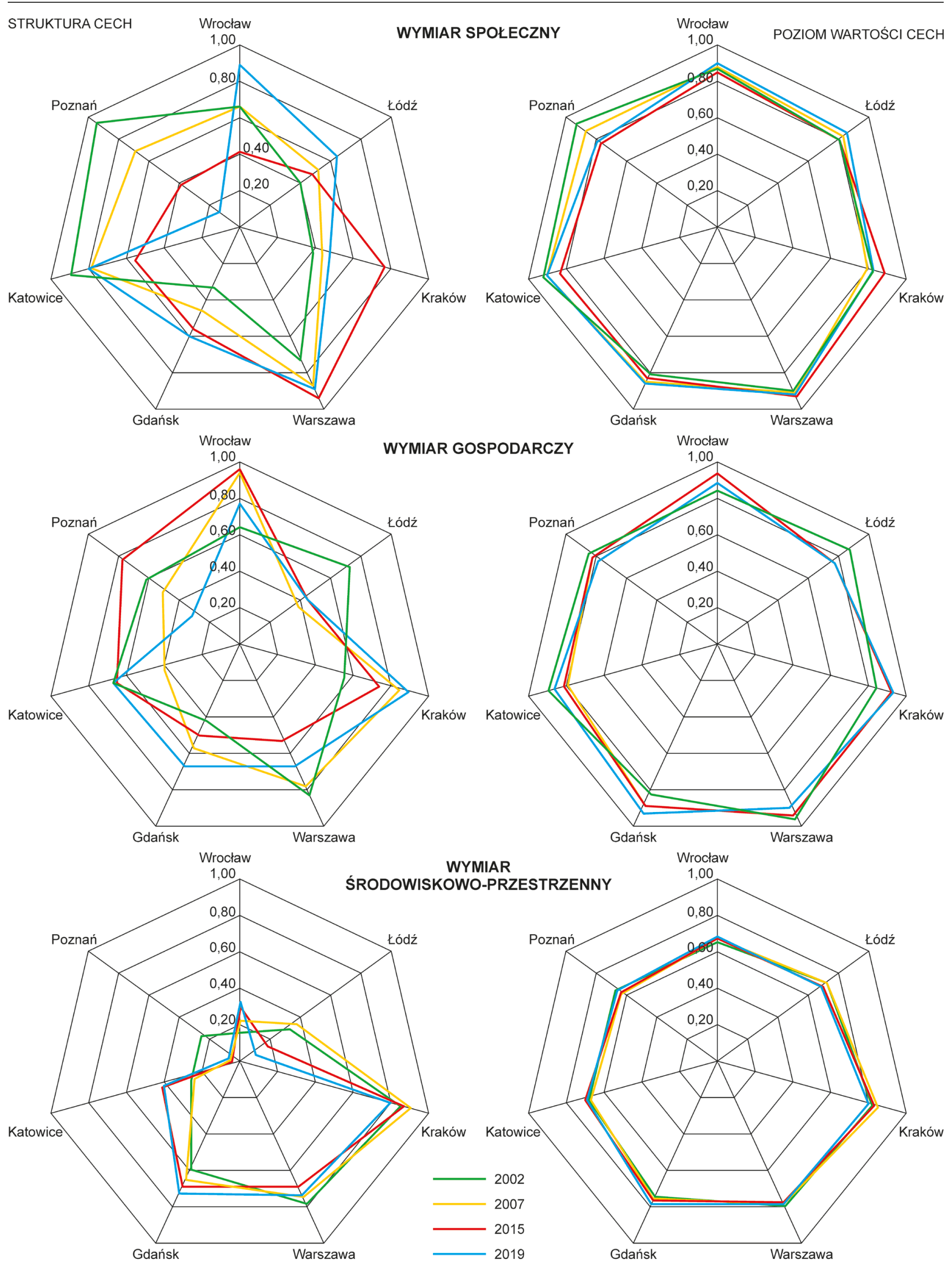

Rysunek 2. Struktura oraz poziom wartości cech w poszczególnych wymiarach zrównoważonego rozwoju Źródło: opracowanie własne 


\section{WNIOSKI}

Polskie miasta metropolitalne są jednostkami, w których koncentrują się inwestycje i nowoczesne działalności gospodarcze, napływa do nich głównie ludność z najbliższego regionu (wyjątek stanowi Warszawa) (Węcławowicz, Łotocka, Baucz, 2010). Charakteryzują się wyższym poziomem życia niż w pozostałych dużych miastach Polski, co sprawia, że zwiększa się zróżnicowanie społeczno-przestrzenne $\mathrm{w}$ miastach i na obszarach metropolitalnych. Równocześnie w miastach metropolitalnych występują problemy społeczne $-\mathrm{w}$ przestrzeni miast pojawiają się enklawy nędzy, będące następstwem nie tylko bezrobocia, ale również niskich kwalifikacji i marginalizacji na rynku pracy. Proces globalizacji gospodarki miast powoduje, że niektóre grupy zawodowe nie mogą rywalizować o dobrze płatne miejsca pracy. Dodatkowo przekształcenia własnościowe oraz prywatyzacja i brak subsydiowania gospodarki mieszkaniowej skutkują silną segregacją mieszkaniową w przestrzeni miasta według kryterium majątkowego ludności (Węcławowicz, Łotocka, Baucz, 2010). Ponadto wpływ na różny poziom rozwoju miast metropolitalnych mają czynniki endo- i egzogeniczne (wielkości, funkcjonalności, przynależności do danego obszaru) (Korenik, Korenik, 2017) oraz polityka miejska prowadzona w miastach, jak i polityka państwa prowadzona wobec miast. Istotne jest uwzględnienie w tej kwestii wytycznych UE i realizacja 17 celów rozwoju zrównoważonego lub priorytetów strategii na rzecz trwałego rozwoju „Europa 2020” (Komunikat Komisji Europa 2020, 2010). Zatem pojawia się pytanie, jakie są efekty realizowanych działań i polityk miast metropolitalnych $\mathrm{w}$ odniesieniu do założeń koncepcji zrównoważonego rozwoju? Porównanie tych jednostek wydaje się trudne w oparciu jedynie o wskaźniki opisujące poszczególne wymiary rozwoju zrównoważonego. Podjęto zatem próbę przedstawienia ich poziomów rozwoju z wykorzystaniem metody taksonomicznej i w oparciu o hipotetyczną jednostkę wzorcowa, stworzoną na podstawie najlepszych miar charakteryzujących badane jednostki. Poziomy rozwoju miast metropolitalnych w badanych momentach czasowych są bardzo zbliżone i wskazują na ich podobieństwo w poszczególnych wymiarach. Jednak dostrzec można pewne różnice, analizując również strukturę cech opisujących poszczególne miasta.

Obszary silnie zurbanizowane, do których należą miasta metropolitalne, mają kluczowe znaczenie dla realizacji polityki zrównoważonego rozwoju kraju oraz UE. Metropolie stanowią znaczący motor napędowy gospodarki, tworzą miejsce spotkań kultury, kreatywności oraz innowacji, są także centrami usług świadczonych dla społeczności miasta, a także obszarów je otaczających. Z uwagi na wysoką gęstość zaludnienia na ich terenie szczególnie wzrasta ryzyko występowania zagrożenia życia i zdrowia mieszkańców w dużej skali. Katastrofy transportowe bądź ekologiczne, zagrożenia epidemiologiczne i inne dotykają od razu dużej liczby mieszkańców na gęsto zabudowanym obszarze. Miasta posiadają znaczący potencjał w zakresie oszczędności energii i przekształceń w kierunku gospodarki niskoemisyjnej. Ośrodki metropolitalne dysponują szerokim wachlarzem usług, mogących spełniać potrzeby mieszkańców, ale równocześnie są miejscami koncentracji takich problemów, jak bezrobocie, segregacja i ubóstwo. Polskie miasta metropolitalne są zróżnicowane pod względem wielkości, możliwości i różnego typu uwarunkowań rozwoju, a tym samym ich sposoby na realizowanie zrównoważonego rozwoju są odmienne. Znaczenie mają takie czynniki, jak prowadzona wewnętrzna polityka miasta, wyznaczone cele rozwojowe i możliwości reagowania na występujące problemy i zgłaszane potrzeby. Analiza wybranych momentów czasowych wskazuje na znaczną dynamikę zmian zachodzących w Poznaniu oraz Katowicach. Z tym że Poznań, na tle pozostałych badanych miast, charakteryzuje się zmianami niekorzystnymi - osiagnnięte wartości przedstawianych miar są dalekie od wzorcowych. Natomiast w przypadku Katowic trend jest odmienny i wskazuje na pożądany charakter zachodzących przeobrażeń. Warszawa jest miastem dominującym zwłaszcza w wymiarze społecznym, w wymiarze gospodarczym prym wiodą Wrocław oraz Kraków, zaś w wymiarze środowiskowo-przestrzennym Kraków.

\section{PRZYPISY}

\footnotetext{
${ }^{1}$ Stymulant - cecha, której pożądane są wyższe wartości (np. PKB - im wyższy, tym gospodarka lepiej się rozwija).

${ }^{2}$ Destymulant - cecha, której pożądane są niższe wartości (np. stopa bezrobocia - im niższa, tym lepsza).
}

\section{BIBLIOGRAFIA}

Brundtland, G.H. (1987). Our Common Future, Report of the World Commission on Environment and Development. Oxford: Oxford University Press.

Ciegis, R., Ramanauskiene, J., Martinkus, B. (2009). The concept of sustainable development and its use for sustainability scenarios. Engineering economics, 62 (2), 28.

Dembicka-Niemiec, A. (2017). Zrównoważony rozwój a funkcje miast: badanie zwiazków między zrównoważonym rozwojem średnich miast w Polsce a ewolucja ich struktury funkcjonalnej. Opole: Wydawnictwo Uniwersytetu Opolskiego.

Ekins, P. (1992). A four-capital model of wealth creation. W:P. Ekins, M. Max-Neef (red.), Real-life economics: Understanding wealth creation (s. 147-151). London-New York: Routledge. 
Elkington, J. (1994). Enter triple bottom line. Pobrane z: https:// www.johnelkington.com/archive/TBL-elkington-chapter.pdf (20.03.2020).

Global Compact Network Poland (2021). Pobrane z: https://ungc. org.pl/sdg/sustainable-develompent-goals/ (19.02.2021).

Grzelońska, U., Kolanowska, E. (1991). Nasza wspólna przyszłość. Raport Światowej Komisji do Spraw Środowiska i Rozwoju. Warszawa: Państwowe Wydawnictwo Ekonomiczne.

Harris, J.M. (2003). Sustainability and sustainable development. International Society for Ecological Economics, 1 (1), 1-12. Pobrane z: https://www.researchgate.net/publication/237398200 Sustainability_and_Sustainable_Development (20.03.2020).

Ilnicki, D. (2003). Miasta polskie jako potencjalne metropolie o znaczeniu kontynentalnym (próba identyfikacji). W: I. Jażdżewska (red.), Funkcje metropolitalne $i$ ich rola w organizacji przestrzeni. XVI Konwersatorium Wiedzy o Mieście (s. 61-72). Łódź: Łódzkie Towarzystwo Naukowe.

Komunikat Komisji Europa 2020 (2010). Strategia na rzecz inteligentnego i zrównoważonego rozwoju sprzyjajacego właczeniu społecznemu. Pobrane z: https://ec.europa.eu/eu2020/pdf/1_ PL_ACT_part1_v1.pdf (20.03.2020).

Koncepcja Przestrzennego Zagospodarowania Kraju 2030 (2011). Pobrane z: http://www.wzs.wzp.pl/sites/default/files/ files/19683/89272000_1412985316_Koncepcja_Przestrzennego_ Zagospodarowania_Kraju_2030.pdf (20.03.2020).

Korenik, S., Korenik, A. (2017). Rozwój metropolii jako przejaw postępującego procesu urbanizacji. Prace Naukowe Uniwersytetu Ekonomicznego we Wrocławiu, 467, 47-56. Pobrane z: https:// dbc.wroc.pl/dlibra/publication/40699/edition/36863/content (20.02.2021).

Markowski, T., Marszał, T. (2006). Metropolie, obszary metropolitalne, metropolizacja. Problemy i pojęcia podstawowe. Warszawa: Polska Akademia Nauk, Komitet Przestrzennego Zagospodarowania Kraju.

Michalski, T. (2001). Zastosowanie miar taksonomicznych do oceny procesu integracji Polski z Unią Europejską. Gospodarka
Narodowa. The Polish Journal of Economics, 172 (11-12), 69-92. Pobrane z: http://yadda.icm.edu.pl/yadda/element/bwmeta1. element.doi-10_33119_GN_113930 (20.03.2020). https://doi. org/10.33119/GN/113930

Moffatt, I. (2000). Ecological footprints and sustainable development. Ecological economics, 32 (3), 361. https://doi. org/10.1016/S0921-8009(99)00117-2

Raworth, K. (2017). Doughnut economics: Seven ways to think like

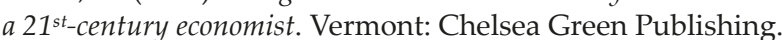

Rzeńca, A. (2016). Ekomiasto\#Środowisko. Zrównoważony inteligentny i partycypacyjny rozwój miasta. Łódź: Wydawnictwo Uniwersytetu Łódzkiego.

Smętkowski, M., Jałowiecki, B., Gorzelak, G. (2009). Obszary metropolitalne w Polsce - diagnoza i rekomendacje. Studia Regionalne i Lokalne, 1 (35), 59-60.

Stangel, M. (2013). Kształtowanie współczesnych obszarów miejskich w kontekście zrównoważonego rozwoju. Gliwice: Wydawnictwo Politechniki Śląskiej.

System Analiz Samorządowych (2020). Pobrane z: https://systemanaliz.pl/ (20.03.2020).

Szwed, D., Maciejewska, B. (2010). Zrównoważony rozwój metropolii Silesia. Gdańsk: Wydawnictwo Fundacja Przestrzenie Dialogu. Pobrane z: http://www.feswar.org.pl/fes2009/pdf_doc/raport_ zrownowazony_rozwoj_metropolia_silesia.pdf (20.10.2020).

Węcławowicz, G., Łotocka, M., Baucz, A., (red.) (2010). Rozwój miast w Polsce, Raport wprowadzajacy Ministerstwa Rozwoju Regionalnego opracowany na potrzeby przygotowania przegladu OECD Krajowej Polityki Miejskiej w Polsce. Warszawa: Ministerstwo Rozwoju Regionalnego.

Zuzańska-Żyśko, E. (2016). Procesy metropolizacji. Teoria i praktyka. Warszawa: Wydawnictwo Naukowe PWN.

Artykuł wpłynął:

15 kwietnia 2020

Zaakceptowano do druku:

1 grudnia 2020 


\section{ZAŁĄCZNIK 1}

Wskaźniki zrównoważonego rozwoju przyjęte do badania

\begin{tabular}{|c|c|c|c|}
\hline & $\begin{array}{l}\text { Wymiary zrównoważonego rozwoju } \\
\text { oraz nazwy wskaźników }\end{array}$ & $\begin{array}{l}\text { Charakter } \\
\text { cechy }\end{array}$ & Opis cechy \\
\hline \multicolumn{4}{|c|}{ Wymiar społeczny } \\
\hline 1 & $\begin{array}{l}\text { Przyrost naturalny na } 1000 \text { mieszkańców } \\
\text { (w promilach) }\end{array}$ & S & \multirow{2}{*}{$\begin{array}{l}\text { Zarówno przyrost naturalny, jak i wyższa gęstość } \\
\text { zaludnienia miasta świadczyć mogą o tym, że jest to } \\
\text { atrakcyjne miejsce do życia, zapewniające możliwość } \\
\text { zaspokajania potrzeb społeczności lokalnej } \\
\end{array}$} \\
\hline 2 & Gęstość zaludnienia - liczba ludności na km² & S & \\
\hline 3 & Apteki na 1000 mieszkańców & S & Zaspokajają potrzeby mieszkańców \\
\hline 4 & Wydatki na ochronę zdrowia na 1 mieszkańca (zł/os.) & S & $\begin{array}{l}\text { To środki finansowe ponoszone przez państwo w celu za- } \\
\text { spokojenia potrzeb publicznych w zakresie ochrony zdro- } \\
\text { wia i opieki medycznej. Zatem im wyższe są wydatki, } \\
\text { tym wyposażenie i obsługa w tym zakresie jest lepsza }\end{array}$ \\
\hline 5 & $\begin{array}{l}\text { Wydatki na oświetlenie ulic, placów i dróg } \\
\text { w przeliczeniu na } 1 \text { mieszkańca (zł) }\end{array}$ & S & $\begin{array}{l}\text { Wyższy udział tych wydatków świadczyć może m.in. } \\
\text { o dbaniu o estetykę przestrzeni miasta i bezpieczeństwo, } \\
\text { co wpływa na poprawę jakości życia jego mieszkańców }\end{array}$ \\
\hline 6 & $\begin{array}{l}\text { Wydatki na gospodarkę mieszkaniową ogółem } \\
\text { na } 1 \text { mieszkańca (zł/os.) }\end{array}$ & S & $\begin{array}{l}\text { Wyższy udział tych wydatków wskazuje na rozwój } \\
\text { mieszkalnictwa, które jest ściśle powiązane z rozwojem } \\
\text { miasta oraz na zaspokojenie potrzeb mieszkaniowych } \\
\text { mieszkańców }\end{array}$ \\
\hline 7 & $\begin{array}{l}\text { Wydatki majątkowe na gospodarkę mieszkaniową } \\
\text { w przeliczeniu na } 1 \text { mieszkańca (zł/os.) }\end{array}$ & S & $\begin{array}{l}\text { Wydatki majątkowe obejmują: } \\
\text { - wydatki na zakup i objęcie akcji oraz wniesienie } \\
\text { wkładów do spółek prawa handlowego, } \\
\text { - wydatki inwestycyjne państwowych jednostek budże- } \\
\text { towych, } \\
\text { - dotacje celowe na finansowanie lub dofinansowanie } \\
\text { kosztów inwestycji realizowanych przez inne jednostki. } \\
\text { Zatem w ujęciu gospodarki mieszkaniowej, wydatki te } \\
\text { traktowane są jako pożądane, gdyż świadczą o przedsię- } \\
\text { biorczym charakterze gminy i jej rozwoju w celu zaspo- } \\
\text { kajania potrzeb mieszkańców }\end{array}$ \\
\hline 8 & $\begin{array}{l}\text { Wydatki na zieleń w miastach i gminach } \\
\text { na } 1 \text { mieszkańca (zł) }\end{array}$ & S & $\begin{array}{l}\text { Wyższy udział tych wydatków świadczyć może m.in. } \\
\text { o dbaniu o estetykę terenów zielonych, co wpływa na } \\
\text { poprawę jakości życia jego mieszkańców }\end{array}$ \\
\hline 9 & $\begin{array}{l}\text { Czytelnicy bibliotek publicznych } \\
\text { na } 1000 \text { mieszkańców }\end{array}$ & $\mathrm{S}$ & $\begin{array}{l}\text { Ich liczba świadczy o poziomie wykształcenia i zainte- } \\
\text { resowań społeczności miasta }\end{array}$ \\
\hline \multicolumn{4}{|c|}{ Wymiar gospodarczy } \\
\hline 1 & Wydatki budżetu gminy na 1 mieszkańca (zł/os.) & S & $\begin{array}{l}\text { Wielkość wydatków świadczy o przedsiębiorczości gmi- } \\
\text { ny i o jej rozwoju }\end{array}$ \\
\hline 2 & $\begin{array}{l}\text { Udział wydatków majątkowych inwestycyjnych } \\
\text { w wydatkach budżetu ogółem (\%) }\end{array}$ & S & \multirow{2}{*}{$\begin{array}{l}\text { Ten rodzaj wydatków świadczy o skłonności do in- } \\
\text { westycji, jak i potencjale inwestycyjnym gminy, który } \\
\text { warunkuje rozwój gospodarczy }\end{array}$} \\
\hline 3 & Wydatki majątkowe inwestycyjne na 1 mieszkańca (zł) & S & \\
\hline 4 & $\begin{array}{l}\text { Stopa zatrudnienia - liczba pracujących } \\
\text { na } 1000 \text { mieszkańców }\end{array}$ & S & $\begin{array}{l}\text { Jest to wskaźnik, który wskazuje odsetek zatrudnionej } \\
\text { ludności w wieku od } 15 \text { do } 64 \text { r.ż., zaznaczając, że pra- } \\
\text { cują oni zawodowo. Im wyższa jest stopa zatrudnienia, } \\
\text { tym korzystniejsza sytuacja społeczności miasta }\end{array}$ \\
\hline 5 & Liczba miejsc noclegowych na 1000 mieszkańców & $\mathrm{S}$ & \multirow{3}{*}{ Wskaźniki te świadczą o atrakcyjności turystycznej miasta } \\
\hline 6 & Liczba udzielonych noclegów na 1000 mieszkańców & S & \\
\hline 7 & $\begin{array}{l}\text { Noclegi udzielone turystom zagranicznym } \\
\text { w obiektach noclegowych na } 10 \text { tys. mieszkańców }\end{array}$ & S & \\
\hline 8 & $\begin{array}{l}\text { Wydatki na gospodarkę odpadami } \\
\text { na } 1 \text { mieszkańca gminy }\end{array}$ & S & \multirow{3}{*}{$\begin{array}{l}\text { Wydatki te świadczą o: } \\
\text { - reagowaniu na potrzeby oczyszczania miasta, } \\
\text { - dbaniu o gospodarkę odpadami, } \\
\text { - ochronie klimatu }\end{array}$} \\
\hline 9 & $\begin{array}{l}\text { Wydatki na ochronę powietrza atmosferycznego } \\
\text { i klimatu na } 1 \text { mieszkańca gminy }\end{array}$ & S & \\
\hline 10 & $\begin{array}{l}\text { Wydatki na oczyszczanie miast i wsi } \\
\text { na } 1 \text { mieszkańca gminy }\end{array}$ & S & \\
\hline
\end{tabular}


Wskaźniki zrównoważonego rozwoju przyjęte do badania (cd.)

\begin{tabular}{|c|c|c|c|}
\hline & $\begin{array}{l}\text { Wymiary zrównoważonego rozwoju } \\
\text { oraz nazwy wskaźników }\end{array}$ & $\begin{array}{l}\text { Charakter } \\
\text { cechy }\end{array}$ & Opis cechy \\
\hline \multicolumn{4}{|c|}{ Wymiar środowiskowo-przestrzenny } \\
\hline 1 & $\begin{array}{l}\text { Powierzchnia obszarów prawnie chronionych jako } \\
\% \text { powierzchni gminy }\end{array}$ & S & \multirow{2}{*}{$\begin{array}{l}\text { Występowanie obszarów prawnie chronionych ozna- } \\
\text { cza, że miasto dysponuje terenami zielonymi, zaspo- } \\
\text { kajającymi potrzeby społeczności miejskiej w zakresie } \\
\text { spędzania wolnego czasu czy rekreacji }\end{array}$} \\
\hline 2 & $\begin{array}{l}\text { Powierzchnia obszarów prawnie chronionych w ha } \\
\text { na } 1000 \text { mieszkańców }\end{array}$ & $S$ & \\
\hline 3 & Wydatki na zieleń na 1 mieszkańca (zł) & $S$ & \multirow{2}{*}{$\begin{array}{l}\text { Wydatki te świadczą o utrzymywaniu terenów zielo- } \\
\text { nych. Wyższe wydatki mogą świadczyć o lepszej este- } \\
\text { tyce terenów zielonych oraz ich prawidłowym zagospo- } \\
\text { darowaniu }\end{array}$} \\
\hline 4 & $\begin{array}{l}\text { Udział wydatków na oczyszczanie gminy } \\
\text { w wydatkach budżetu ogółem (\%) }\end{array}$ & $S$ & \\
\hline 5 & $\begin{array}{l}\text { Ścieki komunalne i przemysłowe (razem) } \\
\text { nieoczyszczane w ogólnej ilości wytwarzanego } \\
\text { ścieku }\end{array}$ & $\mathrm{D}$ & $\begin{array}{l}\text { Im większa jest ilość ścieków nieoczyszczanych tym } \\
\text { większe zagrożenie dla środowiska }\end{array}$ \\
\hline 6 & Zużycie wody na mieszkańca ( $\mathrm{m}^{3} /$ rok) & $\mathrm{D}$ & $\begin{array}{l}\text { Duże zużycie wody przez mieszkańców świadczyć } \\
\text { może o niskiej świadomości ekologicznej }\end{array}$ \\
\hline 7 & $\begin{array}{l}\text { Emisja dwutlenku siarki w t/rok ogółem z zakładów } \\
\text { szczególnie uciążliwych na km² }\end{array}$ & $\mathrm{D}$ & \multirow{3}{*}{$\begin{array}{l}\text { Im większa emisja, tym większe negatywne oddziały- } \\
\text { wanie na jakość powietrza i środowisko }\end{array}$} \\
\hline 8 & $\begin{array}{l}\text { Emisja tlenku węgla w t/rok ogółem z zakładów } \\
\text { szczególnie uciążliwych na km² }\end{array}$ & $\mathrm{D}$ & \\
\hline 9 & $\begin{array}{l}\text { Emisja zanieczyszczeń w t/rok gazowych (bez } \\
\text { dwutlenku węgla) ogółem z zakładów szczególnie } \\
\text { uciążliwych na } \mathrm{km}^{2}\end{array}$ & $\mathrm{D}$ & \\
\hline
\end{tabular}

Objaśnienia: S - stymulanta, D - destymulanta.

Źródło: opracowanie własne. 